\title{
Catalytic Synthesis and Antifungal Activity of New Polychlorinated Natural Terpenes
}

\author{
Hana Ighachane, ${ }^{1}$ Brahim Boualy, ${ }^{2}$ Mustapha Ait Ali, ${ }^{3}$ My. H. Sedra, ${ }^{1,4}$ \\ Larbi El Firdoussi, ${ }^{3}$ and Hassan Bihi Lazrek ${ }^{1}$ \\ ${ }^{1}$ Laboratory of Biomolecular and Medicinal Chemistry, URAC 16, Faculty of Sciences Semlalia, Marrakech, Morocco \\ ${ }^{2}$ Laboratoire de Chimie et Modélisation Mathématique, Faculté Polydisciplinaire de Khouribga, Université Hassan 1er, \\ BP 145, 25000 Khouribga, Morocco \\ ${ }^{3}$ Equipe de Chimie de Coordination et Catalyse, Département de Chimie, Faculté des Sciences Semlalia, Université Cadi Ayyad, \\ BP 2390, 40001 Marrakech, Morocco \\ ${ }^{4}$ Laboratory of Phytopathology, Genetics and Integrated Control (LPGLI), National Institute of Agricultural Research (INRA), \\ P.O. Box 533, Marrakesh, Morocco
}

Correspondence should be addressed to Larbi El Firdoussi; elfirdoussi@uca.ac.ma and Hassan Bihi Lazrek; hblazrek50@gmail.com Received 2 May 2017; Accepted 1 June 2017; Published 9 July 2017

Academic Editor: Michele Fedel

Copyright (C) 2017 Hana Ighachane et al. This is an open access article distributed under the Creative Commons Attribution License, which permits unrestricted use, distribution, and reproduction in any medium, provided the original work is properly cited.

\begin{abstract}
Various unsaturated natural terpenes were selectively converted to the corresponding polychlorinated products in good yields using iron acetylacetonate in combination with nucleophilic cocatalyst. The synthesized compounds were evaluated for their in vitro antifungal activity. The antifungal bioassays showed that $\mathbf{2} \mathbf{c}$ and $\mathbf{2 d}$ possessed significant antifungal activity against Fusarium oxysporum f. sp. albedinis (Foa), Fusarium oxysporum f. sp. canariensis (Foc), and Verticillium dahliae (Vd).
\end{abstract}

\section{Introduction}

Terpenes are naturally occurring molecules derived from isoprene units that have demonstrated therapeutic activities with a wide spectrum of biological activity, including antiinflammatory, antitumor, and fungicidal properties $[1,2]$. They are considered as convenient starting materials for the synthesis of a large and diverse collection of bioactive compounds [3]. Furthermore, they are commercially available, inexpensive, and generally accessible in enantiomeric forms [4].

Catalytic functionalization is a well-established process in organic synthesis and an efficient method for the preparation of high added value products [5-8], among which is catalyzed Kharasch addition or atom transfer radical addition (TMC ATRA) which is an effective tool for carbon-carbon bond formation and has gained considerable interest in organic synthesis during the last 50-60 years [9-11]. On the other hand, it is a synthetically useful process for functionalizing organic compounds by means of halogen derivatives with a high level of atom economy. Kharasch addition is typically catalyzed by transition metal complexes of $\mathrm{Cu}, \mathrm{Ru}, \mathrm{Fe}$, or $\mathrm{Ni}$ $[10,12-14]$. However, although the Kharasch addition of $\mathrm{CCl}_{4}$ to simple alkenes has been extensively studied [12-14], to our knowledge no works have been devoted to the corresponding reactions using natural terpenic alkenes.

On the other hand, by 2050 food request is expected to increase up to $98 \%$; this is due to the global population that has quadrupled over the last century [15]. Thus more attention is required to protect agricultural product from different deleterious factors such as the contamination caused by Verticillium dahliae Kleb. (Vd) which is a broadly distributed vascular soil-borne pathogen that causes Verticillium wilt and it has a large host range, with over 300 plant species known to be susceptible to this fungal pathogen [16, 17]. Fusarium oxysporum f. sp. albedinis (Foa) is the most injurious fungus species affecting date palm (Phoenix dactylifera) especially in Morocco and Algeria [18] and Fusarium oxysporum f. sp. canariensis (Foc) that infect date palm (Phoenix canariensis) has now spread worldwide [19]. These phytopathogenic fungi 
are hard to control. Thus there is growing interest for discovering and developing a new antifungal agent especially using natural compound for plant protection.

In the course of our studies on monoterpenes and their derivatives, we have recently reported an extremely efficient method for the preparation of various allylic terpenic chlorides [14, 20-23]. Following our catalysis objective, we became interested in the preparation of a new class of polychlorinated natural product using Kharasch addition of $\mathrm{CCl}_{4}$ catalyzed by iron acetylacetonate and to evaluate their inhibition capacity of the growth of the three pathogenic microorganisms.

\section{Materials and Methods}

NMR studies were performed on a Bruker Avance 300 spectrometer in $\mathrm{CDCl}_{3}$; chemical shifts are given in ppm relative to external TMS and coupling constant $(J)$ in $\mathrm{Hz}$. Mass spectra were recorded on AMD 402 spectrometer $(70 \mathrm{eV}, \mathrm{EI})$. The reaction mixtures were analyzed on a Trace GC Thermo Finnigan chromatograph equipped with an FID detector (flame ionization detector). GC parameters for capillary columns BP $(25 \mathrm{~m} \times 0.25 \mathrm{~mm}$, SGE) were as follows: injector $250^{\circ} \mathrm{C}$; detector $250^{\circ} \mathrm{C}$; oven $70^{\circ} \mathrm{C}$ for 5 minutes and then $3^{\circ} \mathrm{C} /$ minute until $250^{\circ} \mathrm{C}$ for 30 minutes; column pressure $20 \mathrm{kPa}$, column flow $6.3 \mathrm{~mL} /$ minute; linear velocity $53.1 \mathrm{~cm} / \mathrm{s}$; total flow $138 \mathrm{~mL} /$ minute. Liquid chromatography was performed on silica gel (Merck 60, 220-440 mesh; eluent: hexane). Analytical thin-layer chromatography (TLC) was conducted on Merck aluminium plates with $0.2 \mathrm{~mm}$ of silica gel 60F-254. All the reagents and solvents used in the experiments were purchased from commercial sources and used as received without further purification (Aldrich, Acros).

2.1. General Procedure for Atom Transfer Radical Addition. In a $15 \mathrm{~mL}$ rotaflow Schlenk, we mixed $1 \mathrm{~mol} \%$ of Fe(acac) $(0.0414 \mathrm{mmol}), 5 \mathrm{~mol} \%$ of NEt $_{3}(20.9 \mathrm{mg}, 0.207 \mathrm{mmol})$, olefin ( $4.14 \mathrm{mmol})$, and $\mathrm{CCl}_{4}(2.55 \mathrm{~g}, 16.56 \mathrm{mmol})$. The solvent was added to bring the total volume to $5 \mathrm{~mL}$. The resulting solution was stirred at $80^{\circ} \mathrm{C}$, and the reaction was monitored by TLC. The reaction was quenched by the slow addition of saturated aqueous $\mathrm{Na}_{2} \mathrm{SO}_{3}$. The layers were separated and the aqueous layer was extracted with $\mathrm{CH}_{2} \mathrm{Cl}_{2}(2 \times 10 \mathrm{~mL})$. The combined organic layer was dried over anhydrous $\mathrm{Na}_{2} \mathrm{SO}_{4}$. The solvent was removed under reduced pressure. Pure chlorinated products were obtained by column chromatography over silica gel. All isolated pure products were fully characterized by ${ }^{1} \mathrm{H}$ and ${ }^{13} \mathrm{C}$ NMR and MS.

\subsection{Spectral Data for the Products}

2.2.1. 4-(1-Chloro-1-methyl-ethyl)-1-(2,2,2-trichloro-ethyl)-cyclohexene $2 \boldsymbol{a}$ [22]. ${ }^{1} \mathrm{H}$ NMR $\left(300 \mathrm{MHz}, \mathrm{CDCl}_{3}\right) \delta: 5.71(\mathrm{~m}$, $1 \mathrm{H}), 3.28(\mathrm{~s}, 2 \mathrm{H}), 2.29(\mathrm{~m}, 3 \mathrm{H}), 1.97(\mathrm{~m}, 2 \mathrm{H}), 1.65(\mathrm{~m}, 1 \mathrm{H})$, $1.53(\mathrm{~s}, 3 \mathrm{H}) .{ }^{13} \mathrm{C}$ NMR $\left(75 \mathrm{MHz} \mathrm{CDCl}_{3}\right) \delta: 131.03(\mathrm{Cq}), 130.53$ $(\mathrm{CH}=\mathrm{C}), 99.06\left(\mathrm{CCl}_{3}\right), 73.07(\mathrm{CCl}), 62.02\left(\mathrm{CH}_{2}-\mathrm{CCl}_{3}\right), 45.73$ $(\mathrm{CH}), 30.61\left(\mathrm{CH}_{2}\right) 29.83\left(\mathrm{CH}_{3}\right), 28.19\left(\mathrm{CH}_{3}\right), 24.56\left(\mathrm{CH}_{2}\right)$. ESI-MS $m / z:[\mathrm{M}+\mathrm{H}]^{+} 292.03$.
2.2.2. 1-Methyl-4-(1,3,3,3-tetrachloro-1-methyl-propyl)-7-oxabicyclo[4.1.0] heptane 2c. ${ }^{1} \mathrm{H}$ NMR $\left(300 \mathrm{MHz}, \mathrm{CDCl}_{3}\right) \delta$ : $3.22(\mathrm{~m}, 1 \mathrm{H}), 2.91(\mathrm{~s}, 2 \mathrm{H}), 2.12(\mathrm{~m}, 2 \mathrm{H}), 1.65(\mathrm{~m}, 1 \mathrm{H}), 1.27(\mathrm{~s}$, $3 \mathrm{H}), 1.13(\mathrm{~s}, 3 \mathrm{H}) .{ }^{13} \mathrm{C}$ NMR $\left(75 \mathrm{MHz}, \mathrm{CDCl}_{3}\right) \delta: 131.03(\mathrm{Cq})$, $130.53(\mathrm{CH}=\mathrm{C}), 99.06\left(\mathrm{CCl}_{3}\right), 73.07(\mathrm{CCl}), 62.02\left(\mathrm{CH}_{2}-\mathrm{CCl}_{3}\right)$, $45.73(\mathrm{CH}), 30.61\left(\mathrm{CH}_{2}\right) 29.83\left(\mathrm{CH}_{3}\right), 28.19\left(\mathrm{CH}_{3}\right), 24.56$ $\left(\mathrm{CH}_{2}\right)$. ESI-MS $m / z:[\mathrm{M}+\mathrm{H}]^{+} 307.07$.

2.2.3. 2-Methyl-5-(1,3,3,3-tetrachloro-1-methyl-propyl)-cyclohex-2-enone $2 \boldsymbol{d}$ [23]. ${ }^{1} \mathrm{H} \mathrm{NMR}\left(300 \mathrm{MHz}, \mathrm{CDCl}_{3}\right) \delta: 6.77(\mathrm{~m}$, $1 \mathrm{H}), 3.42(\mathrm{~s}, 2 \mathrm{H}), 2.30-2.80(\mathrm{~m}, 6 \mathrm{H}), 1.90(\mathrm{~s}, 3 \mathrm{H}), 1.79(\mathrm{~s}, 3 \mathrm{H})$. ${ }^{13} \mathrm{C}$ NMR (75 MHz, $\left.\mathrm{CDCl}_{3}\right) \delta: 195.50(\mathrm{C}=\mathrm{O}), 143.52(\mathrm{CH}=\mathrm{C})$, $135.50(\mathrm{C}=\mathrm{C}), 94.46\left(\mathrm{CCl}_{3}\right), 73.42(\mathrm{CCl}), 62.37\left(\mathrm{CH}_{2}-\mathrm{CCl}_{3}\right)$, $45.88(\mathrm{CH}), 39.50\left(\mathrm{CH}_{2}\right) 27.72\left(\mathrm{CH}_{2}\right), 27.32\left(\mathrm{CH}_{3}\right), 15.50$ $\left(\mathrm{CH}_{3}\right)$. ESI-MS $m / z:[\mathrm{M}+\mathrm{H}]^{+} 289.10$.

2.2.4. 1-Methyl-4-(1,3,3,3-tetrachloro-1-methyl-propyl)-cyclohexene $2 \boldsymbol{e} .{ }^{1} \mathrm{H}$ NMR $\left(300 \mathrm{MHz}, \mathrm{CDCl}_{3}\right) \delta: 3.4(\mathrm{~m}, 1 \mathrm{H}), 3.3(\mathrm{~s}$, $2 \mathrm{H}), 2.2-1.95(\mathrm{~m}, 7 \mathrm{H}), 1.8(\mathrm{~s}, 3 \mathrm{H}), 1.65(\mathrm{~s}, 3 \mathrm{H}) .{ }^{13} \mathrm{C} \mathrm{NMR}$ $\left(75 \mathrm{MHz}, \mathrm{CDCl}_{3}\right) \delta: 131.5(\mathrm{Cq}), 118.4(\mathrm{CH}=\mathrm{C}), 73.8\left(\mathrm{CCl}_{3}\right)$, $63.0(\mathrm{CCl}), 46.7\left(\mathrm{CH}_{2}-\mathrm{CCl}_{3}\right), 44.2(\mathrm{CH}), 30.6\left(\mathrm{CH}_{2}\right) 27.2$ $\left(\mathrm{CH}_{2}\right), 25.1\left(\mathrm{CH}_{3}\right), 24.2\left(\mathrm{CH}_{2}\right), 23.2\left(\mathrm{CH}_{3}\right)$. ESI-MS m/z: [M $+\mathrm{H}^{+} 291.08$.

2.2.5. 4a,5-Dimethyl-3-(1,3,3,3-tetrachloro-1-methyl-propyl)-1, 2,3,4,4a,5,6,7-octahydro-naphthalene 2f. ${ }^{1} \mathrm{H} \mathrm{NMR}(300 \mathrm{MHz}$, $\left.\mathrm{CDCl}_{3}\right) \delta: 5.35(\mathrm{~m}, 1 \mathrm{H}), 3.34(\mathrm{~s}, 2 \mathrm{H}), 2.29(\mathrm{~m}, 3 \mathrm{H}), 1.97(\mathrm{~m}$, $2 \mathrm{H}), 1.65(\mathrm{~m}, 1 \mathrm{H}), 1.53(\mathrm{~s}, 3 \mathrm{H}) .{ }^{13} \mathrm{C} \mathrm{NMR}\left(75 \mathrm{MHz}, \mathrm{CDCl}_{3}\right) \delta$ : $142.20(\mathrm{Cq}), 120.71(\mathrm{CH}=\mathrm{C}), 94.75\left(\mathrm{CCl}_{3}\right), 75.28(\mathrm{CCl}), 62.41$ $\left(\mathrm{CH}_{2}-\mathrm{CCl}_{3}\right), 46.40(-\mathrm{CH}-), 45.00(\mathrm{Cq}), 41.11(-\mathrm{CH}-), 40.99$ $\left(\mathrm{CH}_{2}\right), 33.24\left(\mathrm{CH}_{2}\right), 29.83\left(\mathrm{CH}_{2}\right), 27.70\left(\mathrm{CH}_{3}\right), 27.00\left(\mathrm{CH}_{2}\right)$, $25.80\left(\mathrm{CH}_{2}\right), 18.50\left(\mathrm{CH}_{3}\right), 16.20\left(\mathrm{CH}_{3}\right)$. ESI-MS m/z: $[\mathrm{M}+$ $\mathrm{H}]^{+} 359.20$.

\subsection{Antifungal Assays}

2.3.1. Experimental Protocol. In $250 \mathrm{~mL}$ Erlenmeyer flasks, we prepared various solution under aseptic and sterilized condition. $1.25,2.5,5$, and $7.5 \mu \mathrm{g} / \mathrm{mL}$ of each compound were previously dissolved in $0.1 \%$ dimethyl sulfoxide (DMSO); the solution was added to $100 \mathrm{~mL}$ of Czapek solid medium at $45^{\circ} \mathrm{C}$ and then poured into Petri dishes.

Pelt (trademark: Procida Groups Roussel Uclaf) which is a systemic fungicide containing $70 \%$ methyl thiophanate was used as a standard antifungal compound and was also prepared with the same concentrations. The control water is used under the same conditions.

Mycelial discs of $5 \mathrm{~mm}$ diameter, from young cultures of Fusarium oxysporum f. sp. albedinis (Foa), Fusarium oxysporum f. sp. canariensis (Foc), or Verticillium dahliae (Vd) which were provided by Laboratory LPGLI of INRA Marrakech, Morocco (Centre Regional de Recherche Agronomique), and maintained in Czapek medium, were disposed in the middle of the Petri dishes. Incubation was done at $28^{\circ} \mathrm{C}$ under continuous light. Mycelial growth of colonies was estimated every 2 days for 8 days of incubation by the average of two perpendicular diameters $[24,25]$. The values represent the average of 5 independent experiments. 
For measuring sporulation on different media, a single block of $5 \mathrm{~mm}$ diameter was cut out from the fungal colony near the margin by sterilized cork borer and was transferred to $100 \mathrm{~mL}$ sterile distilled water in a test tube, where it was mixed thoroughly to make a uniform spore suspension. Two dilutions of $10^{-5}$ and $10^{-6}$ were prepared from the mother solution. The fungal suspension was then stirred using a vortex for 20 seconds to release spores conidiophores. For each dilution we took $1 \mathrm{~mL}$ of the solution being distributed in a Petri dish. These experiments were repeated five times.

2.3.2. Evaluation of Mycelial Growth. The inhibition rate of mycelial growth of three fungi was calculated using the following formula [24, 25]:

$$
\text { Growth inhibition rate }=\left(\frac{\left(D_{\mathrm{co}}-D_{t}\right)}{D_{\mathrm{co}}}\right) \times 100,
$$

where $D_{\text {co }}=$ colony diameter of the control (water) and $D_{t}=$ colony diameter of the test plate.

2.3.3. Evaluation of Sporulation. We proceeded to count the total number of spores using a Malassez cell. The inhibition percentage of the sporulation is calculated using the following formula [24, 26]:

$$
\begin{aligned}
& \text { Sporulation inhibition rate (\%) } \\
& =\left(\frac{\left(N_{\mathrm{co}}-N_{t}\right)}{N_{\mathrm{co}}}\right) \times 100,
\end{aligned}
$$

where $N_{\text {co }}=$ estimated number of germinated spores of the control (water) and $N_{t}=$ estimated number of germinated spores of the test plate.

2.3.4. Statistical Analysis. Calculations and comparisons of treatment means for each experiment were conducted using analysis of variance (ANOVA) and the SPSS 20.0 software; means were separated by Tukey Honestly Significant Difference (Tukey HSD) test at $P=0.05$.

\section{Results and Discussion}

3.1. Chemical Result. The synthesis of the target compounds was accomplished using our previously optimized catalytic system for the Kharasch addition of tetrachloromethane to olefins under mild reaction conditions [14]. Using various transition metal acetylacetonates $\mathrm{M}(\mathrm{acac})_{n}(\mathrm{M}=\mathrm{Zn}, \mathrm{Co}, \mathrm{V}$, $\mathrm{Ni}, \mathrm{Mo}, \mathrm{Mn}, \mathrm{Fe}$, and $\mathrm{Cr}$ ) and triethylamine as cocatalyst and iron complex highlighting its potential as an effective catalyst, the reactions offer the halogen derivatives in moderate to good yields. Encouraged by these results, we were interested to apply this catalytic system to some mono- and sesquiterpenes in order to synthesize a new series of polyorganochloride products. The Kharasch addition reaction requires either a free radical precursor as the promoter or a metal complex as the catalyst. The classical free radical chain mechanism is operative not only with initiators such as light, heat, and peroxides [27-29] but also with a variety of metal complexes (Scheme 1) [27].

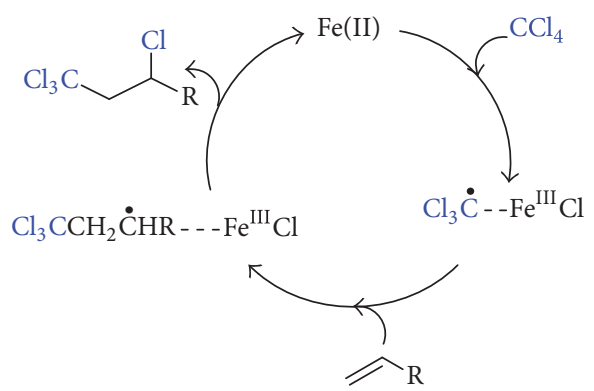

Scheme 1: Proposed mechanism for Kharasch addition of $\mathrm{CCl}_{4}$ to olefins catalyzed by $\mathrm{Fe}(\mathrm{acac})_{2}$.

The addition of tetrachloromethane to unsaturated terpenes can be obtained by treatment with $\mathrm{CCl}_{4}, \mathrm{Fe}(\mathrm{acac})_{2}$ as catalyst, and $\mathrm{NEt}_{3}$ in dry acetonitrile at $80^{\circ} \mathrm{C}$. A possible mechanism for Kharasch reaction is shown in Scheme 1. As proposed by Murai et al. [30] and Kameyama and Kamigata [31] in ruthenium catalyzed Kharasch reaction, we can assume that low-valent iron species probably react in a similar way as $\mathrm{Ru}^{\mathrm{II}}$ catalysts. At this stage, we cannot exclude a multiple-step process that involves radical intermediates as described by Oldroydg et al. [29].

In a typical experiment, $\mathrm{NEt}_{3}$ as cocatalyst [14] was added to a solution of $\mathrm{Fe}(\mathrm{acac})_{2}$ in toluene at $80^{\circ} \mathrm{C}$ and after $15 \mathrm{~min}$ $\mathrm{CCl}_{4}$ was added. The reaction mixture was stirred for $30 \mathrm{~min}$ and then terpene $\mathbf{l a}-\mathbf{f}$ was added. The progress of the reaction was monitored by TLC and GC-MS. The final mixture was filtered through anhydrous $\mathrm{K}_{2} \mathrm{CO}_{3}$ and the filtrate was evaporated under vacuum. The polyorganochlorides $\mathbf{2 a}-\mathbf{f}$ were then purified by flash column chromatography. Reaction times, chemical yields, and conversions are reported in Table 1 . The addition of tetrachloromethane to $\beta$-pinene $\mathbf{1 a}$ and $\alpha$-pinene $\mathbf{1 b}$ led to the formation of the adduct $\mathbf{2 a}$ in excellent yields $(86 \%$ and $85 \%$, resp.) after opening the cyclobutane ring. Limonene oxide $1 \mathrm{c}$ reacted selectively with $\mathrm{CCl}_{4}$ and led to the corresponding adduct $2 \mathrm{c}$ in $63 \%$ yield.

In order to investigate the competition reaction between two carbon-carbon double bonds present in $\mathbf{1 d}$ and 1e, Kharasch addition was then carried out on limonene le to lead selectively towards the monoadduct product $\mathbf{2 e}$ in $77 \%$ yield, corresponding to the activation of the exocyclic double bond. Likewise, the reaction with carvone $\mathbf{l d}$ leads to $\mathbf{2 d}$ in $68 \%$ yield (Table 1). The reaction of sesquiterpene was tested using valencene If and led to the corresponding product $\mathbf{2 f}$ in $74 \%$ yield. We characterized the structures of all products by ${ }^{1} \mathrm{H}-\mathrm{NMR},{ }^{13} \mathrm{C}-\mathrm{NMR}$, and mass spectrometry. In addition, the structure of $\mathbf{2 d}$ was confirmed by X-ray crystallographic analysis $[22,23]$.

The reaction between iron complex and $\mathrm{CCl}_{4}$ leads to the formation of radical $\mathrm{CCl}_{3}$ which reacts with $\beta$-pinene. The reaction occurs through a "ligand-transfer" mechanism (inner-sphere electron transfer) (Scheme 2) [26-29].

3.2. Screening of Antifungal Activity In Vitro. The compounds $\mathbf{2 a}-\mathbf{f}$ and the reference drug were screened for their potential in vitro antifungal activity against three plant pathogenic 
TABLE 1: Synthesis of polyorganochloride $2 \mathbf{a}-\mathbf{f}$.

\begin{tabular}{|c|c|c|c|c|}
\hline Entry & Olefins & Products & Conversion $^{\mathrm{a}}(\%)$ & Yield $^{\mathrm{b}}(\%)$ \\
\hline 1 & & & 96 & 86 \\
\hline 2 & & & 95 & 85 \\
\hline 3 & & & 73 & 63 \\
\hline 4 & & & 83 & 68 \\
\hline 5 & & & 90 & 77 \\
\hline 6 & & & 93 & 74 \\
\hline
\end{tabular}

Reaction conditions. Olefin/ $\mathrm{CCl}_{4}(0.25), \mathrm{Fe}(\mathrm{acac})_{2}\left(0.01\right.$ equiv.), solvent (toluene), triethylamine (0.05 equiv.), and temperature $\left(80^{\circ} \mathrm{C}\right)$, for $24 \mathrm{~h} .{ }^{\mathrm{a}} \mathrm{Conversion}$ based on GC. ${ }^{\text {I } \text { Isolated yield. }}$

fungi (Fusarium oxysporum f. sp. canariensis (Foc), Fusarium oxysporum f. sp albedinis (Foa), and Verticillium dahliae $(\mathrm{Vd}))$. The results are listed in Tables 2 and 3.

As shown in Table 2, almost all the title compounds $\mathbf{2 a - f}$ displayed activities in varying degrees against the tested fungi. We noticed also that the compounds are more active against the Foc and Foa than Vd. The rate of the inhibition varied among the synthesized molecules. The first bioassay using mycelia growth rate method indicated the following result.

For the F.o. f. sp. canariensis (Foc), we observed that compounds $\mathbf{2 c}$ and $\mathbf{2 d}$ had the highest activities at the concentration of $7.5 \mu \mathrm{g} / \mathrm{mL}$, the inhibition rate was around $90 \%$ and
57\% $(P<0.001)$, respectively, and at the concentration of $5 \mu \mathrm{g} / \mathrm{mL}$ the inhibition rate was $75 \%$ and $41 \%$, respectively, while we noticed that for the concentrations $2.50 \mu \mathrm{g} / \mathrm{mL}$ and $1.25 \mu \mathrm{g} / \mathrm{mL}$ some of the compounds did not have any effect.

On the other hand, it seems from the results reported in Table 2 that compounds $\mathbf{2} \mathbf{c}$ and $\mathbf{2 d}$ also showed the greater inhibition rates $(86 \%, 73 \%$ and $100 \%, 85 \%)(P<0.001)$ at $5 \mu \mathrm{g} / \mathrm{mL}$ and $7.5 \mu \mathrm{g} / \mathrm{mL}$, respectively, against F.o. f. sp. albedinis (Foa). Compound $2 \mathrm{c}$ exhibited parallel activity as pelt which is in our case a positive control. As for the evaluation of the in vitro activity of the compounds against Verticillium dahliae ( $V d)$, the results, therefore, suggest that compounds 
TABLE 2: Linear growth inhibition of (Foc, Foa, and Vd) under the effect of different concentrations of the polyorganochlorine derivatives $(\mathbf{2 a}-\mathbf{f})$ in comparison with the control, after 8 days of incubation at $28^{\circ} \mathrm{C}$ on Czapek medium.

\begin{tabular}{|c|c|c|c|c|c|c|c|}
\hline & \multirow{2}{*}{ Concentrations $(\mu \mathrm{g} / \mathrm{mL})$} & \multicolumn{6}{|c|}{ Mycelial growth inhibitory rates (means $\%)^{* *}$} \\
\hline & & $2 \mathbf{a}$ & $2 c$ & $2 d$ & $2 \mathrm{e}$ & $2 \mathrm{f}$ & Pelt \\
\hline \multirow{4}{*}{ Foc } & 1.25 & $-1.69^{c}$ & $15.82^{\mathrm{b}}$ & $1.56^{\mathrm{c}}$ & $-0.72^{\mathrm{c}}$ & $-12.18^{\mathrm{d}}$ & $94.73^{\mathrm{a}}$ \\
\hline & 2.5 & $2.4^{\mathrm{d}}$ & $52.7^{\mathrm{b}}$ & $10.62^{\mathrm{c}}$ & $7.95^{\mathrm{c}}$ & $0.62^{\mathrm{d}}$ & $100^{\mathrm{a}}$ \\
\hline & 5 & $11.67^{\mathrm{f}}$ & $75^{\mathrm{b}}$ & $41^{\mathrm{c}}$ & $33.33^{\mathrm{d}}$ & $21.67^{\mathrm{e}}$ & $100^{\mathrm{a}}$ \\
\hline & 7.5 & $23.8^{\mathrm{f}}$ & $91.2^{\mathrm{b}}$ & $57^{\mathrm{C}}$ & $39.4^{\mathrm{d}}$ & $34.5^{\mathrm{d}}$ & $100^{\mathrm{a}}$ \\
\hline \multirow{4}{*}{ Foa } & 1.25 & $-18.34^{\mathrm{e}}$ & $24.03^{\mathrm{b}}$ & $8.65^{\mathrm{c}}$ & $-0.75^{\mathrm{d}}$ & $-24.82^{\mathrm{e}}$ & $94^{\mathrm{a}}$ \\
\hline & 2.5 & $-0.93^{\mathrm{e}}$ & $58.67^{\mathrm{b}}$ & $47.01^{c}$ & $10^{\mathrm{d}}$ & $-2.72^{\mathrm{e}}$ & $100^{\mathrm{a}}$ \\
\hline & 5 & $4.62^{\mathrm{e}}$ & $86^{\mathrm{b}}$ & $73^{c}$ & $30.77^{\mathrm{d}}$ & $3.08^{\mathrm{e}}$ & $100^{\mathrm{a}}$ \\
\hline & 7.5 & $10.3^{\mathrm{d}}$ & $100^{\mathrm{a}}$ & $85^{\mathrm{b}}$ & $42.9^{c}$ & $10^{\mathrm{d}}$ & $100^{\mathrm{a}}$ \\
\hline \multirow{4}{*}{$\mathrm{Vd}$} & 1.25 & $-22.92^{\mathrm{e}}$ & $6.07^{b}$ & $0.54^{\mathrm{c}}$ & $-6.93^{\mathrm{d}}$ & $-7.72^{\mathrm{d}}$ & $92.86^{\mathrm{a}}$ \\
\hline & 2.5 & $-4.68^{e}$ & $44.75^{\mathrm{b}}$ & $29.08^{c}$ & $0^{\mathrm{d}}$ & $0^{\mathrm{d}}$ & $100^{\mathrm{a}}$ \\
\hline & 5 & $8.38^{\mathrm{d}}$ & $63.59^{b}$ & $52.1^{\mathrm{c}}$ & $14.06^{\mathrm{d}}$ & $13.29^{\mathrm{d}}$ & $100^{\mathrm{a}}$ \\
\hline & 7.5 & $18.75^{\mathrm{e}}$ & $84.38^{\mathrm{b}}$ & $71.25^{\mathrm{c}}$ & $34.38^{\mathrm{d}}$ & $31.25^{\mathrm{d}}$ & $100^{\mathrm{a}}$ \\
\hline
\end{tabular}

Note. Foc: Fusarium oxysporum f. sp. canariensis, Foa: Fusarium oxysporum f. sp albedinis, and Vd: Verticillium dahliae. ${ }^{* *}$ Data in the table are the averages of five replicates. Data followed by different lower case letters show statistically significant differences at $P<0.05$ according to Tukey's HSD.

TABLE 3: Inhibition of the spore germination of Foc, Foa, and Vd under the effect of different concentrations of the polyorganochlorine derivatives (2a-f) in comparison with the control, after $48 \mathrm{~h}$ of incubation at $28^{\circ} \mathrm{C}$.

\begin{tabular}{|c|c|c|c|c|c|c|c|}
\hline & \multirow{2}{*}{ Concentrations $(\mu \mathrm{g} / \mathrm{mL})$} & \multicolumn{6}{|c|}{ Spore germination inhibitory rates (means \%) ${ }^{* *}$} \\
\hline & & $2 a$ & $2 c$ & $2 d$ & $2 \mathrm{e}$ & $2 f$ & Pelt \\
\hline \multirow{4}{*}{ Foc } & 1.25 & $-8.35^{\mathrm{e}}$ & $12.11^{\mathrm{b}}$ & $3.73^{c}$ & $-2.93^{c}$ & $-14.73^{\mathrm{d}}$ & $100^{\mathrm{a}}$ \\
\hline & 2.5 & $8.83^{\mathrm{e}}$ & $43.51^{\mathrm{b}}$ & $24.36^{\mathrm{c}}$ & $14.42^{\mathrm{d}}$ & $2.83^{\mathrm{f}}$ & $100^{\mathrm{a}}$ \\
\hline & 5 & $21.36^{\mathrm{e}}$ & $60.77^{\mathrm{b}}$ & $46.68^{c}$ & $35.3^{\mathrm{d}}$ & $18.7^{\mathrm{e}}$ & $100^{\mathrm{a}}$ \\
\hline & 7.5 & $30.4^{\mathrm{e}}$ & $69^{\mathrm{b}}$ & $52^{\mathrm{c}}$ & $42.93^{\mathrm{d}}$ & $23.15^{f}$ & $100^{\mathrm{a}}$ \\
\hline \multirow{4}{*}{ Foa } & 1.25 & $-35.35^{\mathrm{d}}$ & $32.64^{b}$ & $22.83^{c}$ & $-62.29^{e}$ & $-54.41^{\mathrm{e}}$ & $100^{\mathrm{a}}$ \\
\hline & 2.5 & $-18.83^{\mathrm{d}}$ & $53.95^{\mathrm{b}}$ & $44.36^{\mathrm{c}}$ & $-44.82^{\mathrm{e}}$ & $-39.33^{\mathrm{e}}$ & $100^{\mathrm{a}}$ \\
\hline & 5 & $-0.68^{\mathrm{d}}$ & $69.82^{\mathrm{b}}$ & $56.21^{\mathrm{c}}$ & $-21.51^{\mathrm{e}}$ & $-15.67^{\mathrm{e}}$ & $100^{\mathrm{a}}$ \\
\hline & 7.5 & $3.53^{\mathrm{c}}$ & $100^{\mathrm{a}}$ & $63.95^{\mathrm{b}}$ & $-1.48^{\mathrm{c}}$ & $0.34^{\mathrm{c}}$ & $100^{\mathrm{a}}$ \\
\hline \multirow{4}{*}{ Vd } & 1.25 & $-35.35^{\mathrm{e}}$ & $2.37^{\mathrm{b}}$ & $-4.83^{\mathrm{c}}$ & $-12.67^{\mathrm{d}}$ & $-15.23^{\mathrm{d}}$ & $100^{\mathrm{a}}$ \\
\hline & 2.5 & $-28.47^{\mathrm{d}}$ & $13.63^{\mathrm{b}}$ & $8.36^{\mathrm{b}}$ & $-4.85^{\mathrm{c}}$ & $-9.35^{\mathrm{c}}$ & $100^{\mathrm{a}}$ \\
\hline & 5 & $-17.27^{\mathrm{e}}$ & $42.79^{\mathrm{b}}$ & $33.68^{c}$ & $19.19^{\mathrm{d}}$ & $10.42^{\mathrm{d}}$ & $100^{\mathrm{a}}$ \\
\hline & 7.5 & $-5.53^{\mathrm{e}}$ & $68.74^{\mathrm{b}}$ & $53.95^{\mathrm{c}}$ & $35.33^{\mathrm{d}}$ & $30.17^{\mathrm{d}}$ & $100^{\mathrm{a}}$ \\
\hline
\end{tabular}

Note. Foc: Fusarium oxysporum f. sp. canariensis, Foa: Fusarium oxysporum f. sp albedinis, and Vd: Verticillium dahliae. ${ }^{* *}$ Data in the table are the averages of five replicates. Data followed by different lower case letters show statistically significant differences at $P<0.05$ according to Tukey's HSD.

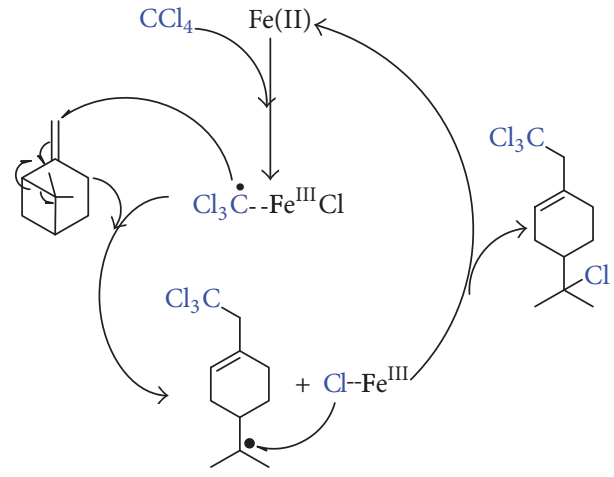

SCHEME 2: Proposed mechanism for the cyclobutane opening ring of $\beta$-pinene in Kharasch addition of $\mathrm{CCl}_{4}$ catalyzed by $\mathrm{Fe}(\mathrm{acac})_{2}$. 2c and $\mathbf{2 d}$ at the concentration of $7.5 \mu \mathrm{g} / \mathrm{mL}$ exhibited the highest inhibition.

The second bioassay was designed to measure fungistatic and fungicidal effects of the compounds by using a sporulation inhibition test. The results of the bioassay were summarized in the tables (Table 3 ). It confirmed that almost all the compounds exhibited fungistatic actions against the tested fungi, the range of inhibition was from -35 to $100 \%$, and the most potent activity was demonstrated against (Foa). This result provided useful information to study the structureactivity relationship for these new structures, shown in Table 1.

Thus, the findings demonstrate that compound $2 \mathrm{c}$ exhibited the highest fungicidal effect against all the fungus 
followed by compound $\mathbf{2 d}$ (Table 3 ). This can be due to the presence of oxygen atom in common limonene oxide $2 \mathrm{c}$ as an epoxy group and carvone $\mathbf{2 d}$ as a carbonyl group; hence the nature of the group in the monoterpene could lead to highest interaction with the biological target. For instance, the evaluation of antifungal activity for diterpene $\mathbf{2} \mathbf{f}$ reveals that this structure significantly decreases antifungal activity and also the inhibition of sporulation.

A large number of studies have been done in recent years on terpenoids as active components showing antifungal activities against various fungi [32]. For instance, polygodial was found to exhibit a fungicidal activity against a food spoilage yeast [33]; the diterpenoids $16 \alpha$-hydroxy-cleroda-3,13-(14)-Zdiene-15,16-olide and 16-oxo-cleroda-3,13-(14)-E-diene-15oic acid also demonstrated significant antifungal activity [34], while methyl angolensate and 1,3,7-trideacetylkhivorin displayed the highest antifungal activity, with 62.8 and $64 \%$ mycelial growth inhibition at $1000 \mathrm{mg} / \mathrm{L}$, respectively, against the plant pathogenic fungus Botrytis cinerea [35, 36]. The results from the present study indicate the antifungal nature of new polychlorinated natural terpenes which showed significant inhibition in linear growth and sporulation against the three fungi (Foc, Foa, and $V d$ ). The antifungal activity of these new compounds was observed for the first time; however, detailed studies regarding its mode of action and efficacy under field condition are needed to be carried out.

\section{Conclusion}

The catalytic Kharasch reaction of $\alpha$-pinene, $\beta$-pinene, limonene, limonene oxide, and valencene was studied using the iron acetylacetonate as catalyst and triethylamine as cocatalyst. The catalytic system showed to be efficient for the addition of carbon tetrachloride to all terpenes used. Regarding biological control of plant disease management, the antifungal bioassays showed that compounds $2 \mathrm{c}$ and $\mathbf{2 d}$ could constitute new lead compounds for further studies to develop antifungal agent against Fusarium oxysporum f. sp. albedinis, Fusarium oxysporum f. sp. canariensis, and Verticillium dahliae.

\section{Conflicts of Interest}

The authors have no conflicts of interest to declare.

\section{Acknowledgments}

This work was supported by the Cadi Ayyad University and by National Institute for Agricultural Research (INRA), Marrakech, Morocco. The authors thank Dr. Ram Chandra Mishra, College of Pharmacy, University of Georgia, Athens, USA, for helpful discussion of this manuscript.

\section{References}

[1] D. S. Johnson and J. J. Li, Innovative Drug Synthesis, John Wiley \& Sons, Hoboken, NJ, USA, p. 360, 2007.

[2] M. L. Bution, G. Molina, M. R. E. Abrahaõ, and G. M. Pastore, "Genetic and metabolic engineering of microorganisms for the development of new flavor compounds from terpenic substrates," Critical Reviews in Biotechnology, vol. 35, no. 3, pp. 313-325, 2015.

[3] G. N. Agrios, Significance of Plant Disease, Plant Pathology Academic Press, London, UK, p. 25, 2000.

[4] A. P. da Silva, M. V. Martini, C. M. A. de Oliveira et al., "Antitumor activity of (-)- $\alpha$-bisabolol-based thiosemicarbazones against human tumor cell lines," European Journal of Medicinal Chemistry, vol. 45, no. 7, pp. 2987-2993, 2010.

[5] W. E. Erman, "Chemistry of the monoterpenes," in Encyclopedic Handbook, vol. 1, p. 832, Marcel Dekker, New York, NY, USA, 1985.

[6] E. V. Gusevskaya, "Organometallic catalysis: Some contributions to organic synthesis," Quimica Nova, vol. 26, no. 2, pp. 242248, 2003.

[7] S. Houssame, H. Anane, L. Firdoussi, and A. Karim, "Palladium(0)-catalyzed amination of allylic natural terpenic functionalized olefins," Central European Journal of Chemistry, vol. 6, no. 3, pp. 470-476, 2008.

[8] B. Boualy, M. A. Harrad, S. El Houssame, L. El Firdoussi, M. A. Ali, and A. Karim, "Copper(II) catalyzed allylic amination of terpenic chlorides in water," Catalysis Communications, vol. 19, pp. 46-50, 2012.

[9] R. A. Gossage, L. A. Van De Kuil, and G. Van Koten, "Diaminoarylnickel(II) "pincer" complexes: mechanistic considerations in the kharasch addition reaction, controlled polymerization, and dendrimeric transition metal catalysts," Accounts of Chemical Research, vol. 31, no. 7, pp. 423-431, 1998.

[10] J. Iqbal, B. Bhatia, and N. K. Nayyar, "Transition metalpromoted free-radical reactions in organic synthesis: The formation of carbon-carbon bonds," Chemical Reviews, vol. 94, no. 2, pp. 519-564, 1994.

[11] M. N. C. Balili and T. Pintauer, "Photoinitiated ambient temperature copper-catalyzed atom transfer radical addition (ATRA) and cyclization (ATRC) reactions in the presence of free-radical diazo initiator (AIBN)," Dalton Transactions, vol. 40, no. 12, pp. 3060-3066, 2011.

[12] K. Severin, "Ruthenium catalysts for the Kharasch reaction," Current Organic Chemistry, vol. 10, no. 2, pp. 217-224, 2006.

[13] V. Dragutan, I. Dragutan, L. Delaude, and A. Demonceau, "NHC-Ru complexes-Friendly catalytic tools for manifold chemical transformations," Coordination Chemistry Reviews, vol. 251, no. 5-6, pp. 765-794, 2007.

[14] B. Boualy, M. A. Harrad, L. El Firdoussi, M. Ait Ali, S. El Houssame, and A. Karim, "Kharasch addition of tetrachloromethane to alkenes catalyzed by metal acetylacetonates," Catalysis Communications, vol. 12, no. 14, pp. 1295-1297, 2011.

[15] H. Valin, R. D. Sands, D. van der Mensbrugghe et al., "The future of food demand: Understanding differences in global economic models," Agricultural Economics (United Kingdom), vol. 45, no. 1, pp. 51-67, 2014.

[16] X. Lan, J. Zhang, Z. Zong, Q. Ma, and Y. Wang, "Evaluation of the biocontrol potential of purpureocillium lilacinum QLP12 against verticillium dahliae in eggplant," BioMed Research International, vol. 2017, pp. 1-8, 2017.

[17] S. J. Klosterman, Z. K. Atallah, G. E. Vallad, and K. V. Subbarao, "Diversity, pathogenicity, and management of Verticillium species," Annual Review of Phytopathology, vol. 47, pp. 3962, 2009.

[18] I. Fhoula, A. Najjari, Y. Turki, S. Jaballah, A. Boudabous, and H. Ouzari, "Diversity and antimicrobial properties of lactic acid 
bacteria isolated from rhizosphere of olive trees and desert truffles of tunisia," BioMed Research International, vol. 2013, Article ID 405708, 14 pages, 2013.

[19] T. V. Feather and H. D. Munnecke, "Wilt and dieback of Canary Island palm in California," California Agriculture, vol. 33, no. 7, pp. 19-20, 1979.

[20] B. Boualy, S. El Houssame, L. Sancineto et al., "A mild and efficient method for the synthesis of a new optically active diallyl selenide and its catalytic activity in the allylic chlorination of natural terpenes," New Journal of Chemistry, vol. 40, no. 4, pp. 3395-3399, 2016.

[21] B. Boualy, L. El Firdoussi, M. A. Ali, and A. Karim, "Allylic chlorination of terpenic olefins using a combination of $\mathrm{MoCl}$ 5 and $\mathrm{NaOCl}$," Journal of the Brazilian Chemical Society, vol. 22, no. 7, pp. 1259-1262, 2011.

[22] B. Boualy, M. A. Harrad, L. E. Firdoussi, M. A. Ali, and C. Rizzoli, "(S)-4-(2-Chloropropan-2-yl)-1-(2,2,2-trichloroethyl)cyclohexene," Acta Crystallographica Section E: Structure Reports Online, vol. 67, no. 4, p. o960, 2011.

[23] B. Boualy, M. A. Harrad, L. El Firdoussi, M. A. Ali, and H. Stoeckli-Evans, "(R)-2-Methyl-5-[(R)-2,4,4,4-tetra-chlorobutan-2-yl]cyclo-hex-2-enone," Acta Crystallographica Section E: Structure Reports Online, vol. 68, no. 8, pp. o2451-o2452, 2012.

[24] H. Ighachane, My. H. Sedra, and H. B. Lazrek, "Synthesis and evaluation of antifungal activities of $(3 \mathrm{H})$-quinazolin-4-one derivatives against tree plant fungi," Journal of Material And Environmental Science, vol. 8, no. 1, pp. 134-143, 2017.

[25] P. Leroux and A. Credet, Etude de l'activité des Fongicides, INRA, Versailles, France, p. 12, 1978.

[26] U. De Corato, E. Viola, G. Arcieri, V. Valerio, F. A. Cancellara, and F. Zimbardi, "Antifungal activity of liquid waste obtained from the detoxification of steam-exploded plant biomass against plant pathogenic fungi," Crop Protection, vol. 55, pp. 109-118, 2014.

[27] R. Grigg, J. Devlin, A. Ramasubbu, R. M. Scott, and P. Stevenson, "Ruthenium (II) - and rhenium(III) -catalysed addition of tetrahalogenomethanes to alkenes and $1, \omega$-dienes. Stereoselective formation of cis-1,2-disubstituted cyclopentanes from 1,6dienes," Journal of the Chemical Society, Perkin Transactions 1, pp. 1515-1520, 1987.

[28] M. S. Kharasch, E. V. Jensen, and W. H. Urry, "Addition of carbon tetrachloride and chloroform to olefins," Science, vol. 102, no. 2640, p. 128, 1945.

[29] D. M. Oldroydg, G. S. Fisher, and L. A. Goldblatt, "The peroxide-catalyzed addition of carbon tetrachloride to $\beta$-pinene," Journal of American Chemical Society, vol. 72, pp. 2407-2410, 1950.

[30] S. Murai, R. Sugise, and N. Sonoda, “[(-)-diop]RhCl—catalyzed asymmetric addition of bromotrichloromethane to styrene," Angewandte Chemie International Edition in English, vol. 20, no. 5, pp. 475-476, 1981.

[31] M. Kameyama and N. Kamigata, "Asymmetric radical reaction in the coordination sphere. iii. asymmetric addition of trichloromethanesulfonyl chloride and carbon tetrachloride to olefins catalyzed by a ruthenium(ii) complex with chiral ligand," Bulletin of the Chemical Society of Japan, vol. 60, no. 10, pp. 3687-3691, 1987.

[32] R. Barkai-Golan, Post Harvest Diseases Fruits and Vegetables, Elsevier, Amsterdam, The Netherlands, pp. 418-424, 2001.

[33] K.-I. Fujita and I. Kubo, "Naturally occurring antifungal agents against Zygosaccharomyces bailii and their synergism," Journal of Agricultural and Food Chemistry, vol. 53, no. 13, pp. 5187-5191, 2005.

[34] M. Marthanda Murthy, M. Subramanyam, M. Hima Bindu, and J. Annapurna, "Antimicrobial activity of clerodane diterpenoids from Polyalthia longifolia seeds," Fitoterapia, vol. 76, no. 3-4, pp. 336-339, 2005.

[35] S. A. M. Abdelgaleil, F. Hashinaga, and M. Nakatani, "Antifungal activity of limonoids from Khaya ivorensis," Pest Management Science, vol. 61, no. 2, pp. 186-190, 2005.

[36] M. J. Abad, M. Ansuategui, and P. Bermejo, "Active antifungal substances from natural sources," Arkivoc, vol. 2007, no. 7, pp. 116-145, 2007. 

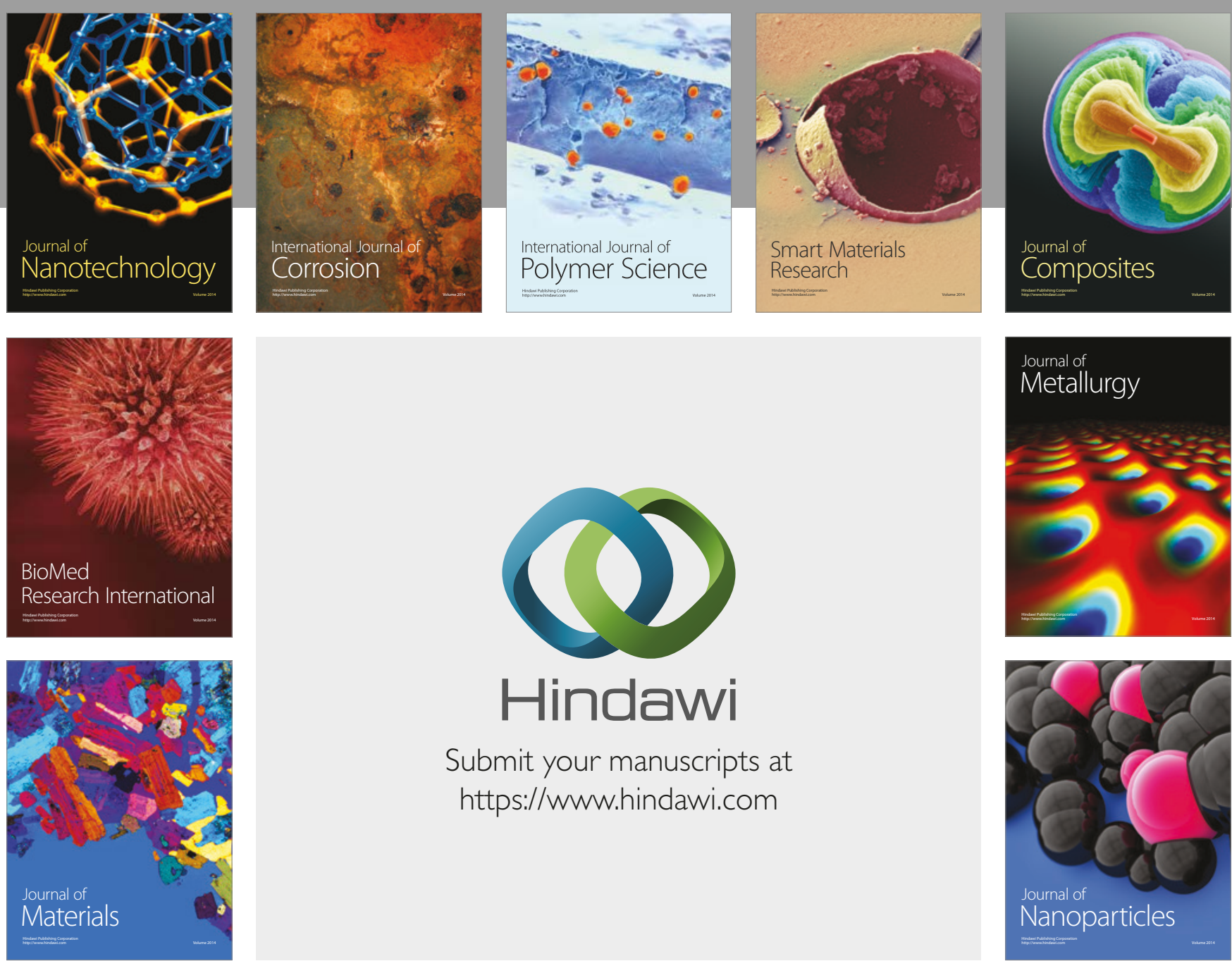

\section{Hindawi}

Submit your manuscripts at

https://www.hindawi.com
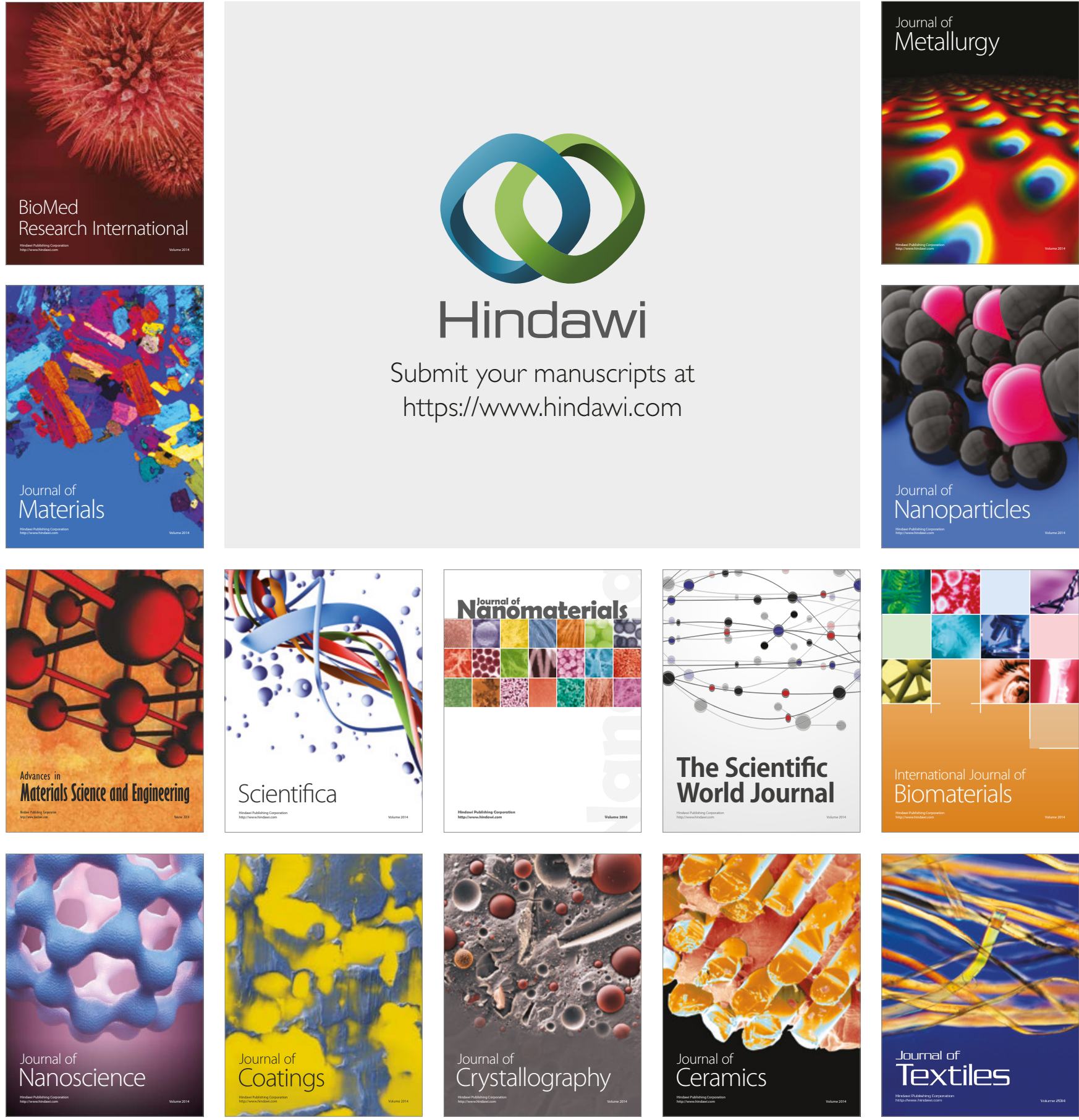

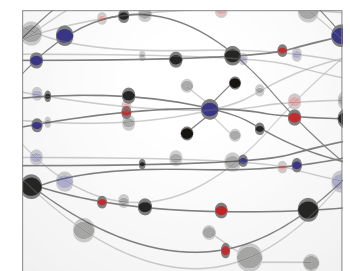

The Scientific World Journal
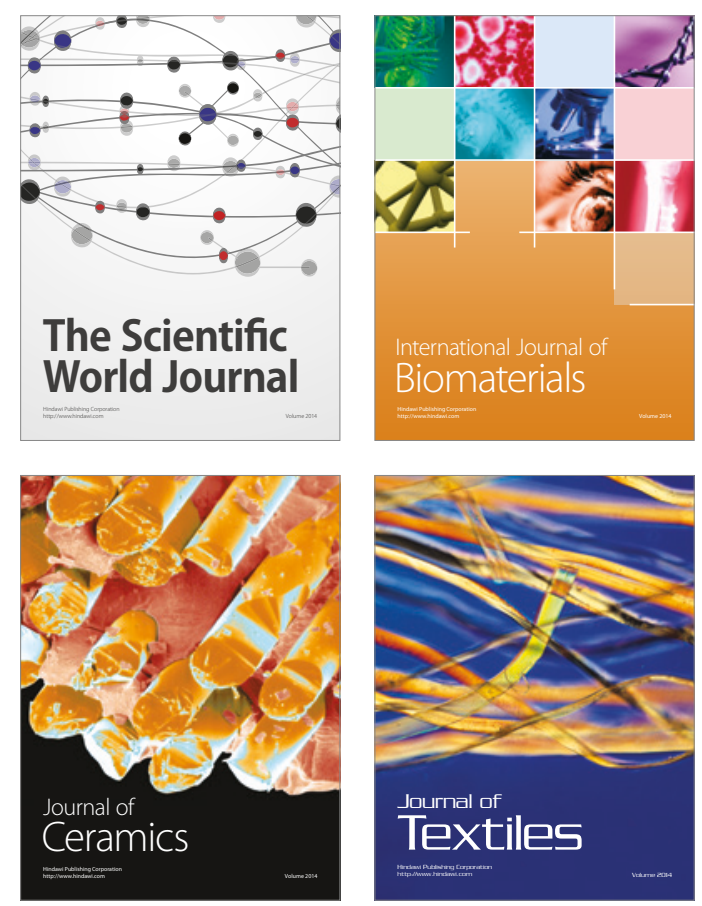